\title{
Communication
}

\section{Partial-Body Cryostimulation Increases Resting Energy Expenditure in Lean and Obese Women}

\author{
Massimo De Nardi ${ }^{1,2}$, Ambra Bisio 2,3@ , Lucio Della Guardia ${ }^{4}$, Carlo Facheris ${ }^{1}$, Emanuela Faelli ${ }^{2,3}{ }^{(1)}$, \\ Antonio La Torre ${ }^{4,5}$ (D) , Livio Luzi ${ }^{4,6}$, Piero Ruggeri ${ }^{2,3}$ (D) and Roberto Codella $4,6, *(D)$ \\ 1 Krioplanet Ltd., Treviglio, 24047 Bergamo, Italy; info@krioplanet.it (M.D.N.); \\ carlo.facheris91@gmail.com (C.F.) \\ 2 Department of Experimental Medicine, Università Degli Studi di Genova, 16132 Genoa, Italy; \\ ambra.bisio@unige.it (A.B.); emanuela.faelli@unige.it (E.F.); ruggeri@unige.it (P.R.) \\ 3 Centro Polifunzionale di Scienze Motorie, Università Degli Studi di Genova, 16132 Genoa, Italy \\ 4 Department of Biomedical Sciences for Health, Università Degli Studi di Milano, 20133 Milano, Italy; \\ lucio.dellaguardia@unimi.it (L.D.G.); antonio.latorre@unimi.it (A.L.T.); livio.luzi@unimi.it (L.L.) \\ 5 IRCCS Istituto Ortopedico Galeazzi, 20161 Milan, Italy \\ 6 Department of Endocrinology, Nutrition and Metabolic Diseases, IRCCS MultiMedica, 20138 Milano, Italy \\ * Correspondence: roberto.codella@unimi.it; Tel.: +39-02-50330356
}

check for updates

Citation: De Nardi, M.; Bisio, A.; Della Guardia, L.; Facheris, C.; Faelli, E.; La Torre, A.; Luzi, L.; Ruggeri, P.; Codella, R. Partial-Body Cryostimulation Increases Resting Energy Expenditure in Lean and Obese Women. Int. J. Environ. Res. Public Health 2021, 18, 4127. https:/ / doi.org/10.3390/ijerph18084127

Academic Editor: Sylvia Kirchengast

Received: 26 February 2021

Accepted: 12 April 2021

Published: 14 April 2021

Publisher's Note: MDPI stays neutral with regard to jurisdictional claims in published maps and institutional affiliations.

Copyright: (c) 2021 by the authors. Licensee MDPI, Basel, Switzerland. This article is an open access article distributed under the terms and conditions of the Creative Commons Attribution (CC BY) license (https:/ / creativecommons.org/licenses/by/ $4.0 /)$.

\begin{abstract}
Cryostimulation is currently seen as a potential adjuvant strategy to tackle obesity and dysmetabolism by triggering cold-induced thermogenesis. Although suggestive, the underlying mechanisms are still poorly elucidated. We tested whether single or repeated applications of partialbody cryostimulation (PBC) could influence resting energy expenditure (REE) in exposed individuals. Fifteen middle-aged obese and sixteen control lean women (body mass index $31 \pm 1.6 \mathrm{~kg} / \mathrm{m}^{2}$ and $\left.22 \pm 1.7 \mathrm{~kg} / \mathrm{m}^{2}\right)$ underwent a daily $\operatorname{PBC}\left(-130{ }^{\circ} \mathrm{C} \times 150 \mathrm{~s}\right)$ for five consecutive days. Resting energy metabolism (REE) was assessed by indirect calorimetry pre- and post-PBC on day 1 and day 5. As concerns REE, the linear mixed model revealed that REE changes were explained by session and time $\left(\mathrm{F}_{1,29}=5.58 ; p=0.02 ; \eta_{\mathrm{p}}{ }^{2}=0.16\right)$ independent of the group $\left(\mathrm{F}_{1,29}=2.9 ; p=0.09\right.$; $\eta_{\mathrm{p}}{ }^{2}=0.09$ ). REE pre-PBC increased from day 1 to day 5 either in leans (by $8.2 \%$, from $1538 \pm 111$ to $1665 \pm 106 \mathrm{kcal} /$ day) or in obese women (by $5.5 \%$, from $1610 \pm 110$ to $1698 \pm 142 \mathrm{vs} \mathrm{kcal} /$ day). Respiratory quotient was significantly affected by the time $\left(\mathrm{F}_{1,29}=51.61 ; p<0.000001, \eta_{\mathrm{p}}{ }^{2}=0.64\right)$, as it increased from pre- to post-PBC, suggesting a shift in substrate oxidation. According to these preliminary data, cold-induced thermogenesis could be explored as a strategy to elevate REE in obese subjects. Longitudinal studies could test whether chronic PBC effects may entail favorable metabolic adaptations.
\end{abstract}

Keywords: cold therapy; white adipose tissue; metabolism; thermogenesis; weight loss; adipocytes; indirect calorimetry; skeletal muscle; obesity treatment; brown adipose tissue

\section{Introduction}

Obesity constitutes a global health burden [1] and is defined as the overexpansion of white adipose tissue (WAT) leading to ponderal excess (BMI $\geq 30 \mathrm{~kg} / \mathrm{m}^{2}$ ). It is commonly featured by a variable degree of low-grade inflammation and immune cells infiltration in WAT [2]. Beyond storing excess energy in the form of triglycerides, WAT functions as an endocrine organ, ensuring metabolic balance. Adipocytes are plastic cells [3] capable of adapting their biological profile according to environmental changes, in the effort to ensure energy homeostasis. When exposed to energy excess, adipocytes undergo morphological and biochemical changes, which promote cell dysfunction and the development of local and systemic inflammatory response [2].

In contrast to WAT, brown adipose tissue (BAT) catabolizes glucose and lipids for thermogenic purposes [4]. Active BAT deposits have been found in the supraclavicular 
and neck regions in humans [5]. Additionally, paravertebral, mediastinal, para-aortic and suprarenal area are interested by functional BAT deposits in adults [5]. Due to high plasticity, white adipocytes are capable to convert to brown-like adipocytes (and vice versa) in response to various stimuli like cold $[4,5]$. Thus, the redirection of white adipocytes or white precursors towards brown phenotype could contribute to control obesity $[4,5]$.

Resting energy expenditure (REE) typically accounts for $60 \%$ to $75 \%$ of total daily energy expenditure and represents the amount of energy required to maintain systemic homeostasis [6]. Individuals with low REE are demonstrated to have an increased risk of developing obesity and related disorders [7-9]. Conversely, the increase of REE could represent a potential resource for weight-loss in obese subjects $[10,11]$.

The increase in energy expenditure upon cold exposure has long been known [12]. Cold exposure increases REE by activating shivering (ST) and the non-shivering thermogenesis (NST) in a number of tissues including WAT, BAT and skeletal muscle. Cold exposure is believed to increase lipid catabolism and adipose tissue-related thermogenesis [10,12], although the mechanisms remain unclear. In humans, BAT increases its metabolic rate and cell number to maintain the body temperature in response to cold. The increased oxidative metabolism in BAT directly contributes to augmented energy expenditure upon cold exposure [10].

Partial body cryostimulation (PBC) consists in brief (60-180 s) exposure to a steam of liquid nitrogen (between $-130{ }^{\circ} \mathrm{C}$ and $-170{ }^{\circ} \mathrm{C}$ ) of the whole body, except for the head and neck [13]. The effect of PBC on obese individuals still represents a poorly explored field of research. Growing attention is being given to this technique as suitable strategy to promote weight loss, ameliorate adipose tissue function and whole-body metabolic homeostasis [14,15] in obese individuals. In fact, PBC has been previously used to reduce pro-inflammatory response, relieve pain and enhance muscles' post-exercise recovery; however, its use as an alternative strategy to trigger cold-induced thermogenesis remains unexplored [16].

The aim of present investigation is to characterize the REE response in lean and obese subjects undergoing PBC, as to providing the mechanistic background for further investigations on the topic.

\section{Materials and Methods}

\subsection{Subjects and Design}

Normal weight and obese middle-aged women were recruited for this study. Based on the a priori sample-sized determination (software G*Power 3.1.9.2, Universität Düsseldorf, Germany), with a statistical power of 0.8 , a probability level of 0.05 , an effect size f of 0.26 with a main effect on REE, 32 young adult women were enrolled for this study. The present investigation was designed as a longitudinal controlled trial.

Subjects underwent a morning single session of PBC/day for 5 consecutive days. On day 1 and 5, before and after each PBC, participants' REE was assessed by indirect calorimetry. Study design is depicted in Figure 1.
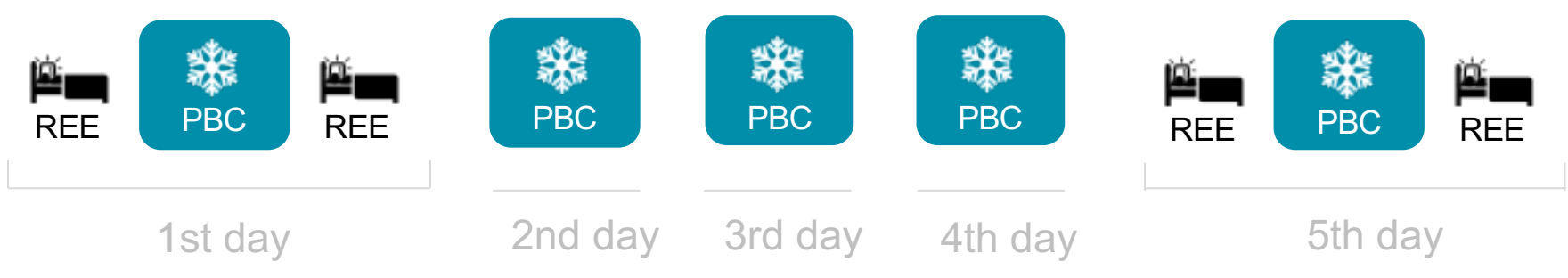

Figure 1. Flow-chart of the study. Obese and lean women underwent multiple exposures of Partial-Body Cryostimulation PBC $(n=5)$. Their Resting Energy Expenditure (REE) was indirectly derived prior and upon completion of the first and fifth day of PBC session. 
Before the intervention, a physician conducted a physical examination of the subjects to exclude any contraindication to PBC. Pharmacological therapy was assessed before the study. People undergoing any pharmacological therapy on a regular basis or taking medication influencing metabolic homeostasis were excluded. In addition, people who had been exposed to cryostimulation procedures within the last 6 months, smokers, alcohol abusers, those following specific diets or taking supplements that may affect the metabolic rate, were also excluded from the trial.

As to the energy balance not deriving from REE, subjects were screened for physical activity levels (IPAQ questionnaire [17]) and caloric and dietary intake (EPIC questionnaire $[18,19])$. Throughout the intervention, participants were encouraged to maintain their physical and dietary habits.

Subjects were given full information about the scope and the methodology of the study, which was approved but Ethics Committee of the Università degli Studi di Milano (Approval $n^{\circ}$ 9/15) in accordance with the Declaration of Helsinki. Finally, subjects signed a written informed consent to participate.

Anthropometrics and REE measurements. Subjects' body weight and height were measured to the nearest of $0.1 \mathrm{~kg}$ and $1 \mathrm{~mm}$, respectively, by using a commercial scale/stadiometer device (Tanita BC 571, Tanita corporation, Tokyo, Japan). BMI was calculated for each individual as weight $(\mathrm{kg}) /$ height $(\mathrm{m})^{2}$ (Table 1$)$.

Table 1. Characteristics of the study subjects.

\begin{tabular}{cccc}
\hline & $\begin{array}{c}\text { Lean } \\
(\boldsymbol{n}=\mathbf{1 6})\end{array}$ & $\begin{array}{c}\text { Obese } \\
(\boldsymbol{n}=\mathbf{1 5})\end{array}$ & $\boldsymbol{p}$ Value \\
\hline Age (years) & $40.4 \pm 6$ & $42.7 \pm 10.4$ & 0.46 \\
Height $(\mathrm{cm})$ & $162.6 \pm 5.5$ & $163.7 \pm 6.8$ & 0.64 \\
Weight $(\mathrm{kg})$ & $58.3 \pm 4.5$ & $83.2 \pm 7.3$ & $<0.0001$ \\
BMI (kg/m $\left.{ }^{2}\right)$ & $22 \pm 1.7$ & $31 \pm 1.6$ & $<0.0001$ \\
Basal REE * (kcal/day) & $1538 \pm 111$ & $1610 \pm 110$ & $<0.0001$ \\
Physical Activity (MET **-min/week) & $1760 \pm 1660$ & $2149 \pm 934$ & 0.7 \\
Dietary intake (kcal/day) & $1254 \pm 191$ & $1432 \pm 820$ & 0.67 \\
\hline Data are & &
\end{tabular}

Data are shown as mean \pm SD. ${ }^{*}$ Resting Energy Expenditure. ${ }^{* *}$ Metabolic Equivalent of Task.

REE was assessed employing a validated [20] indirect calorimeter device (Q-NRG, Cosmed, Rome, Italy) prior and right after PBC application exclusively on day 1 and day 5, of the intervention. Subjects were instructed to observe a proper lifestyle and dietary procedures (fasting, avoid any sport activity and coffee consumption) $24 \mathrm{~h}$ prior to the measurement. Participants were also instructed to attain to specific instructions during the exam for a correct execution of the procedure. All participants were studied at the same hour of the day, two subjects per day, from 7:00 a.m. to 8:00 a.m., approximately. The room was kept in a range of thermoneutrality (around $20-22{ }^{\circ} \mathrm{C}$ ) through the modulating temperature and humidity percentage by means of an air conditioning apparatus. Subjects remained dressed and lying supine on medical examination bed for $10 \mathrm{~min}$, before positioning an isolating plexiglass canopy over their head. After another $10 \mathrm{~min}$ period for acclimatization to the device and for equilibration of experimental parameters, started a $20 \mathrm{~min}$ recording period where participants remained motionless for the entire length of the exam, without closing their eyes and cross their legs. Respiratory gaseous exchanges $\left(\dot{V} \mathrm{CO}_{2}\right.$ and $\left.\dot{V} \mathrm{O}_{2}\right)$ were measured. REE was estimated via software calculation (OMNIA, Cosmed, Rome, Italy); respiratory quotient (RQ) was also estimated as the ratio $\dot{V} \mathrm{CO}_{2} / \dot{V} \mathrm{O}_{2}$, in order to obtain data on the variation of substrate utilization, following the $\mathrm{PBC}$ procedure.

\subsection{Partial-Body Cryostimulation Procedure}

Participants were exposed one by one to very-low temperatures in a cryo-cabin (Cryomed Pro, Criomed, Ltd., Kherson, Ukraine), an open tank equipped with a mobile lift 
which allows to adjust the height of each subject, so the user is exposed to the cold dry air up to the shoulders, with the neck and the head out of the cabin. Each session followed the standard indications [13]: $150 \mathrm{~s}$ at a temperature raging from -130 to $-170{ }^{\circ} \mathrm{C}$. According to the manufacturer's recommendations, each subject wore shorts, a pair of gloves, woolen sock and wooden clogs to prevent the occurrence of frostbites. Participants were instructed by a qualified operator to walk on the same spot and turn around continuously for all the time of the treatment.

\subsection{Statistical Analysis}

All data are expressed as means \pm standard deviation (SD) except where differently indicated. REE results were reported as means of absolute values as well as change in percentage to baseline. Normality of the data was assessed by Shapiro-Wilk test and skewness and kurtosis indexes were also ensured to be both within the conventional cutoff [21]. Baseline characteristics between groups were tested by a two-tailed independent Student's $t$-test.

Mixed model analyses of variance were applied on changes in REE, respiratory quotient (RQ), $\dot{V} C_{2}$ and $\dot{V} \mathrm{O}_{2}$, to compare the effects of $\mathrm{PBC}$ procedure in the two groups (leans vs. obese), the two sessions (day 1 vs. day 5 ) and the time (pre-PBC vs. post-PBC). This approach was chosen to take into account the intrinsic (and uncontrolled) variability among the participants, which was considered everywhere as a random factor.

Post hoc pair-wise comparisons were conducted utilizing Newman-Keul test when interaction effects were demonstrated. The sphericity assumption was examined using Mauchly's test.

Partial eta squared $\left(\eta_{\mathrm{p}}{ }^{2}\right)$ effect sizes (ES) were determined and interpreted using the following cutoffs: small effect, $\eta_{\mathrm{p}}{ }^{2} \leq 0.03$; medium/moderate effect, $0.03<\eta_{\mathrm{p}}{ }^{2}<0.10$; large effect, $0.10 \leq \eta_{\mathrm{p}}{ }^{2}<0.20$; very large effect, $\eta_{\mathrm{p}}{ }^{2} \geq 0.20$ [22]. For all analyses, a $p$ value less than 0.05 was considered statistically significant.

Analyses were carried out with the Statistical Package SPSS version 26 for Mac (Armonk, NY, USA; IBM Corp.), GraphPad Prism 8 (San Diego, CA, USA) and Excel version 16.32 for Mac (Microsoft, Redmond, WA, USA).

\section{Results}

Fifteen obese individuals (BMI $31 \pm 1.6 \mathrm{~kg} / \mathrm{m}^{2}$ ) and 16 lean controls (BMI $22 \pm 1.7 \mathrm{~kg} / \mathrm{m}^{2}$ ) were admitted to this study. One obese subject turned out to be outlier [23] and therefore was not included in the statistical analysis. Subjects' anthropometrical and energy characteristics at baseline are summarized in Table 1.

Baseline REE resulted to be higher in the obese women with respect to lean controls $(1610 \pm 110 \mathrm{kcal}$ vs $1538 \pm 111 \mathrm{kcal} ; p<0.0001)$. Both groups were sedentary according to IPAQ questionnaire. No significant difference was found as to the estimated dietary intake between groups.

\subsection{Multiple PBC Induced Incremental Response in REE in Lean and Obese Women}

We investigated whether sessions of $\mathrm{PBC}$ carried out on five consecutive days might produce greater increase in REE in lean and obese subjects.

REE significantly increased from day 1 to day 5 (session: $\mathrm{F}_{1,29}=21.86 ; p=0.00006$, $\eta_{\mathrm{p}}{ }^{2}=0.43$ ) and from pre- to post-PBC (time: $\mathrm{F}_{1,29}=5.23 ; p=0.03, \eta_{\mathrm{p}}{ }^{2}=0.15$ ). Furthermore, a significant session $\times$ time interaction was found $\left(\mathrm{F}_{1,29}=5.58 ; p=0.025, \eta_{\mathrm{p}}{ }^{2}=0.16\right)$, indicating that REE increased significantly following the first session of $\operatorname{PBC}(p=0.0007)$. Changes of REE after the fifth session of PBC comparing to before fifth session were not statistically significant. However, REE values registered before and after the fifth session of PBC were significantly higher than those registered on session $1(0.001<p<0.05)$.

In lean women, REE values registered before PBC augmented by $8.2 \%$ from day 1 to day 5 (1538 \pm 111 vs $1665 \pm 106 \mathrm{kcal} /$ day; Figure 2). Likewise, in obese women, REE 
values registered before PBC augmented by $5.5 \%$ from day 1 to day 5 (1610 \pm 110 vs $1698 \pm 142 \mathrm{kcal} /$ day; Figure 2).

Mean \pm SD data are reported in Table 2 and in Supplementary File (Table S1). 
Table 2. Study-subjects' results throughout the entire experimental timespan.

\begin{tabular}{|c|c|c|c|c|c|c|c|c|}
\hline & \multicolumn{4}{|c|}{ Lean } & \multicolumn{4}{|c|}{ Obese } \\
\hline & \multicolumn{2}{|c|}{ Day 1} & \multicolumn{2}{|c|}{ Day 5} & \multicolumn{2}{|c|}{ Day 1} & \multicolumn{2}{|c|}{ Day 5} \\
\hline & Pre & Post & Pre & Post & Pre & Post & Pre & Post \\
\hline$\dot{V} \mathrm{O}_{2}(\mathrm{~mL} / \mathrm{min})$ & $224 \pm 15$ & $235 \pm 17$ & $244 \pm 15$ & $242 \pm 17$ & $234 \pm 17$ & $234 \pm 37$ & $248 \pm 21$ & $244 \pm 31$ \\
\hline$\dot{V} \mathrm{CO}_{2}(\mathrm{~mL} / \mathrm{min})$ & $176 \pm 20$ & $203 \pm 16$ & $186 \pm 20$ & $197 \pm 20$ & $186 \pm 17$ & $201 \pm 23$ & $193 \pm 23$ & $212 \pm 24$ \\
\hline $\mathrm{RQ}\left(\dot{V} \mathrm{CO}_{2} / \dot{V} \mathrm{O}_{2}\right)$ & $0.79 \pm 0.06$ & $0.86 \pm 0.08$ & $0.76 \pm 0.07$ & $0.82 \pm 0.07$ & $0.80 \pm 0.08$ & $0.87 \pm 0.11$ & $0.78 \pm 0.09$ & $0.87 \pm 0.07$ \\
\hline REE (kcal/day) & $1538 \pm 111$ & $1645 \pm 107$ & $1665 \pm 106$ & $1676 \pm 115$ & $1610 \pm 110$ & $1632 \pm 229$ & $1698 \pm 142$ & $1706 \pm 203$ \\
\hline
\end{tabular}

Data are shown as mean \pm SD.

\section{5-day sessions of PBC}

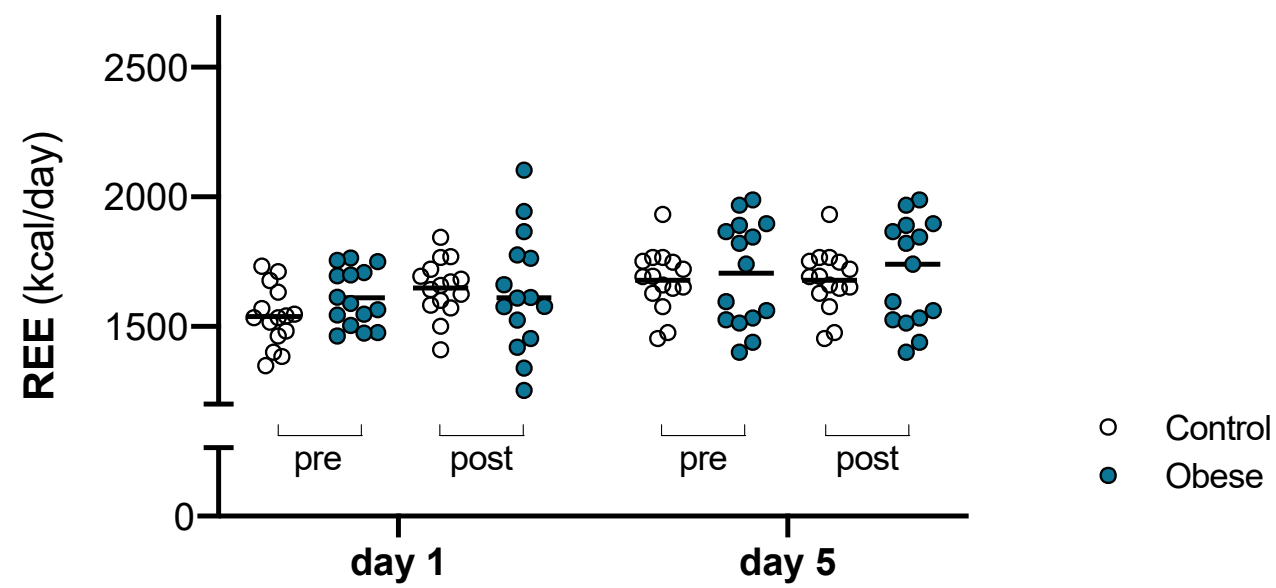

Figure 2. Effects of 5 days of cryostimulation sessions on the REE recorded before and after PBC, on day 1 and day 5 , in obese and lean women (controls). Statistically significant comparisons are indicated in the results section.

\subsection{PBC Induced a Shift in Substrate Oxidation}

$\dot{V} \mathrm{CO}_{2}$ significantly increased from pre- to post-PBC $\left(\mathrm{F}_{1,29}=51.26 ; p=0.00001, \eta_{\mathrm{p}}{ }^{2}=0.64\right)$. Moreover, a significant interaction session $\times$ time $\times$ group was detected for $\dot{V} \mathrm{CO}_{2}\left(\mathrm{~F}_{1,29}=7.948\right.$; $\left.p=0.0085, \eta_{\mathrm{p}}^{2}=0.22\right)$. In lean women, $\dot{V} \mathrm{CO}_{2}$ increased after the first session of PBC comparing to before the first session ( $p=0.0001$, Table 2$)$. The same pattern occurred in session 5 ( $p=0.006$, Table 2). Further, $\dot{V} \mathrm{CO}_{2}$ registered before the first session of PBC was lower than that one registered before the fifth session of $\operatorname{PBC}(p=0.017)$.

In the obese women, $\dot{V} \mathrm{CO}_{2}$ increased significantly after PBC in both sessions (day 1: $p=0.0009$; Day 5: $p=0.0002$. Table 2). Finally, $\dot{V} \mathrm{CO}_{2}$ registered after the first session of $\mathrm{PBC}$ was lower than that one registered after the fifth session of PBC $(p=0.01)$.

$\dot{V} \mathrm{O}_{2}$ significantly increased from day 1 to day $5\left(\mathrm{~F}_{1,29}=26.92 ; p=0.00002, \eta_{\mathrm{p}}{ }^{2}=0.48\right)$. Furthermore, a significant session $\times$ time interaction $\left(\mathrm{F}_{1,29}=4.66 ; p=0.039, \eta_{\mathrm{p}}{ }^{2}=0.14\right)$ showed that $\dot{V} \mathrm{O}_{2}$ augmented after the first session of PBC $(p=0.047$, Table 2). Changes of $\dot{V} \mathrm{O}_{2}$ after the fifth session of $\mathrm{PBC}$ comparing to before fifth session were not statistically significant. However, $\dot{V} \mathrm{O}_{2}$ values registered before and after the fifth session of PBC were significantly higher than those registered on session 1 (always $p<0.001$, Table 2). $\left.\eta_{\mathrm{p}}^{2}=0.64\right)$.

$\mathrm{RQ}$ values significantly increased from pre- to post-PBC $\left(\mathrm{F}_{1,29}=51.61 ; p<0.000001\right.$,

Mean \pm SD data are reported in Table 2 and in Supplementary File (Tables S2-S4). 


\section{Discussion}

To our knowledge, this is the first research aimed at investigating the effect of PBC on REE in lean and obese subjects. Results achieved suggest that a single exposure to controlled cold temperature is sufficient to increase REE by a significant extent. Diversified cold applications elicit an incremental thermogenic effect. This is in accordance with interventions demonstrating adipose tissue loss upon repeated sessions of local cooling [24]. Our results can be seen as a step further in the comprehension of body response to PBC, as to substantiate its utilization in clinical practice.

Obese subjects at baseline presented higher REE values compared to lean subjects (respectively $1610 \pm 110 \mathrm{vs} 1538 \pm 111 \mathrm{kcal} /$ day), as evidenced elsewhere [25]. Both groups reported a dietary energy intake below the measured REE, which is a common finding, especially among obese individuals [26].

Cold-induced thermogenesis can be increased by leveraging on both ST and NST. Different tissues are able to increase their aerobic capacity in the effort to face temperature drop, contributing to increase NST [27]. However, BAT and muscle seem to account for a larger magnitude of cold-induced thermogenesis $[10,28]$. Shivering has not been observed in our intervention neither during nor before the procedure, which suggests that the effect recorded is virtually attributable to the activation of the NST; however, based on variables examined and data considered, the contribution of ST to REE increment cannot be completely ruled out.

Brown and brown-like adipocytes promote energy expenditure through sympatheticactivated thermogenesis which upregulates the uncoupled protein response [4]. Midterm cold exposure was demonstrated to induce a BAT-mediated oxygen consumption in short and long term $(+0.1-0.6 \%$ and $+0.5-2.3 \%$ of whole-body) [29]. Four-week cold exposure led to $45 \%$ increase of BAT volume and $182 \%$ of substrate oxidation from baseline [30]. Previous investigations have shown that cryostimulation procedure was found to increase irisin in lean and obese individuals [15,31]. Irisin is a recently discovered hormone, secreted from skeletal muscles in response to physical activity; it is thought to play a role in boosting thermogenesis in human, thus mediating part of the exercise-induced weight loss. Irisin is currently considered an indirect marker of browning since stimulates the activation of p38 and ERK signaling, enabling UCP-1 expression in adipocytes [32].

In our experiment we found that multiple $\mathrm{PBC}$ applications were able to increase REE to a significative extent in both lean and obese women. Nevertheless, obese people seemed to be less responsive compared to lean controls. Thereby, the higher adiposity in obese subjects seems to blunt the cold-induced increase in REE. In the absence of further substantiating data, we have advanced several possible explanations:

- Brown and Brown-Like Adipocytes Are Less Represented in Obese Compared to Lean Individuals

PET studies demonstrated that BAT activity is inversely related to BMI and lower in obese subjects than in lean subjects [33,34]. As mentioned, energy excess and overnutrition stimulate the brown-to-white conversion [4], reducing the overall mass of brown or brownlike cells suitable to cold-induced metabolic induction. This occurs in the interscapular area as well as single cells interspersed among white deposits [4] with the purpose of augmenting the storage of triglycerides. White adipocytes would then replace brown adipocytes in adipose tissue niches, thus diminishing de facto the quota of metabolically active adipocytes possible augmenting REE. In addition to volume reduction, a diminished activity and biogenesis of mitochondrial BAT in obese can account for the lower response to cold of these individuals $[10,35]$.

- Fat-Free Mass (FFM) and Chiefly Skeletal Muscles Are Likely to Provide a Great Contribution to Cold-Induced Thermogenesis

Beside BAT, an increase in substrate oxidation has been demonstrated in different tissues, upon cold exposure. Recent advances suggest that FFM is pivotal for cold-induced NST $[10,27]$. In skeletal muscle, several mechanisms are activated during cold exposure to generate futile cycles including proton leak, substrates synthesis and degradation and 
sarcoplasmic reticulum $\mathrm{Ca}^{2+}$ ATPase (SERCA), with the result of augmenting heat production and energy expenditure [10]. Proton leak accounts for approximately $10 \%$ of REE in normal conditions and is generated through UCP-3 in muscle [10]. Recent data show that sarcolipin/SERCA interaction plays an important role in muscle-induced thermogenesis and REE increase [28,36]. Molecules such as sarcolipin are demonstrated to trigger SERCA uncoupling activity, increasing ATP hydrolysis and heat production during cold exposure.

- Dysfunctional WAT Impairs Muscle Metabolism Likely Altering Obese Subjects' Thermogenetic Capacity

Obese animals display a reduced thermogenetic capacity in response to cooling [37]. Similarly, in a study of Jung et al., obese subjects with a family history of obesity showed a reduced metabolic response to noradrenaline administration compared with lean subjects [35]. In obesity, the pathological accumulation of lipids in skeletal muscle and the low-grade inflammation impairs insulin signaling [38] and tissue proper glucose uptake and utilization. Similarly, skeletal muscle lipid oxidation is impaired in obesity [39]. Obesity-related mitochondrial dysfunction could be also implicated in the lower rate of substrate oxidation (as testified by the lower increase in $\dot{V} \mathrm{O}_{2}$ in the obese group) [40]. Furthermore, the activity of SERCA was shown to be impaired in animal models of obesity and metabolic syndrome [41,42], potentially representing an adjunctive factor accounting for the poorer response to PBC-induced thermogenesis in the group of obese-women. Thereby, dysmetabolism in obesity could possibly affect muscle substrate oxidation [43], de facto preventing a prompt thermogenic response to cold exposure.

- WAT Response to Cooling Is Probably Poorly Involved in REE Increase in Short-Term Exposure

Energy expenditure following cold exposure can also occur in WAT independently of BAT activation [34]. Both WAT and BAT are capable of metabolizing energy by pathways independent of UCP1 [44]. The activation of resident immune cells upon cold exposure is also suggested to enhance WAT thermogenesis [10]. Moreover, WAT was demonstrated to increase energy expenditure and mitochondrial activity in response to cold [45]. Nonetheless, in our study, WAT contribution seems to be limited. Since no insulating effect of adipose tissue has been evidenced in obesity [46], the dysfunctional metabolic phenotype and the scarcity of brown-like adipocytes in WAT of obese are likely to account for its poorly responsiveness to short-term cooling exposure.

Given a higher increase of REE of lean women with respect to obese ones, when comparing REE_pre-PBC on day 5 vs day 1 , it is possible that the relatively higher FFM/FM in lean subjects as well as the impairment of WAT, BAT and muscle metabolism could be responsible for the putative metabolic refractoriness of obese subjects. At this stage, the lack of detailed subjects' body composition impedes to draw that line of reasoning. Otherwise, one may speculate that repeated sessions of PBC tends to engage BAT to a larger extent, thus promoting a shifting from muscle to BAT-induced thermogenesis.

$\mathrm{RQ}$ increment following each $\mathrm{PBC}$ session, suggests an augmented carbohydrate (CHO) utilization. RQ through a quantitative assessment of respiratory gases $\left(\dot{V} \mathrm{CO}_{2} / \dot{V} \mathrm{O}_{2}\right)$, provides a qualitative, indirect estimation of whole-body substrate oxidation, indicating a prevalent $\mathrm{CHO}$ utilization (when the ratio is close to 1.00) or a larger percentage of lipid oxidation (when the ratio is close to 0.7). Since food habits did not change during intervention, $R Q$ variation is attributable to cold-induced substrate shifting. The shifting to $\mathrm{CHO}$ oxidation is consistent with previous studies on controlled cold exposure [15,31] and investigations showing a scarce lipid mobilization upon local cooling [24]. BAT contains a significant quota of endogenous glycogen [4] and cold exposure in murine model was demonstrated to significantly increase BAT glucose uptake [47]. BAT of triglyceride-lacking mice was shown to employ circulating glucose and stored glycogen to fuel thermogenesis in place of lipids [48,49]. Furthermore, cold-triggered skeletal muscle activation is likely to contribute to glucose oxidation [10]. Conversely, in longer exposures $\mathrm{CHO}$ utilization can be replaced by lipid oxidation as suggested by Blondin et al. [30]. These findings then indicate that probably cold exposure exerts only a modest effect on triglyceride cleavage 
and mobilization in WAT, as suggested by other authors [24]. The higher RQ shifting in obese women (lean and obese women presented the same baseline RQ value) suggests a preferential relative $\mathrm{CHO}$ oxidation in obesity. This finding is supported by the occurrence of impaired fat oxidation in skeletal muscle [39] in obesity and the scarce lipid mobilization observed in obese subjects undergoing local cooling [24]. The impaired fat oxidation can therefore fuel glycogen and/or glucose utilization in BAT and muscles of obese individuals. Our RQ data also suggest that the impaired lipid oxidation in obese are not efficaciously corrected by short-term PBC exposure. However, a relative increase in lipids and protein oxidation cannot be completely ruled out based on RQ data recorded.

The present work was intended as an explorative study to assess the variation of REE upon PBC application. As such, some limitations can be evidenced. First of all, part of the intervention was restricted to only women, therefore lacking generalizability. Women present higher WAT and BAT volumes and a smaller ratio visceral/subcutaneous WAT, with a different pattern of regional distribution compared to men [33,50]. The lack of data on BAT and WAT volumes, adipose tissue specific cytokines and markers of browning (e.g., irisin) further precluded the possibility of an in-depth discussion on BAT and WAT response to PBC as well as speculating on the possible causes of REE increase. Finally, as suggested by previous investigations [15,24], a longer period of PBC application might have likely resulted in a more effective induction of REE. Loap et al. [24], for example, observed that weight loss continued to occur in obese people over a period of 3 months after discontinuing cold exposure. In this view, further investigations are encouraged to test the effect of longer exposure periods.

No adverse events were reported in this study. Future studies are advised to focus on the possible side effects elicited by repeated PBC treatments, evidencing the time-point in which beneficial effects are overruled by possible (if any) side effects.

\section{Conclusions}

To our knowledge, this study was the first to demonstrate that either single or multiple PBC sessions significantly induce the augment of REE in lean and obese women, albeit demonstrating differential effectiveness. Additional studies are granted to investigate the metabolic results secondary to longer treatment periods, mainly focusing on the timeduration of the REE increase gained after PBC. Since evidence on the topic is still embryonic, further evaluations regarding repeated sessions of $\mathrm{PBC}$ therapy in obese subjects are advisable in order to substantiate the employment of this procedure as a possible strategy to significatively augment REE, in this class of patients.

Supplementary Materials: The following are available online at https: / www.mdpi.com/article/10 .3390/ijerph18084127/s1, Table S1: mx linear_mix_mod on resting energy expenditure (REE); Table S2: $\mathrm{mx}$ linear_mix_mod on respirartory quotient (RQ); Table S3. mx linear_mix_mod on $\dot{V} \mathrm{O}_{2}$; Table S4. $m x$ linear_mix_mod on $\dot{V} \mathrm{CO}_{2}$.

Author Contributions: Conceptualization, M.D.N., E.F., R.C.; methodology, M.D.N., C.F.; software, M.D.N., C.F.; validation, M.D.N., R.C.; formal analysis, A.B., R.C.; investigation, M.D.N., C.F.; resources, M.D.N., R.C., A.L.T., L.L., P.R.; data curation, A.B., R.C.; writing-original draft preparation, L.D.G., R.C.; writing-review and editing, M.D.N., A.B., L.D.G., R.C.; visualization, R.C.; supervision, M.D.N., R.C., P.R.; project administration, M.D.N., R.C.; funding acquisition, M.D.N. All authors have read and agreed to the published version of the manuscript.

Funding: This research received no external funding.

Institutional Review Board Statement: The study was conducted according to the guidelines of the Declaration of Helsinki and approved by the Ethics Committee of University of Milan (Approval $\mathrm{n}^{\circ}$ 9/15, 4.03.2015).

Informed Consent Statement: Informed consent was obtained from all subjects involved in the study.

Data Availability Statement: The data presented in this study are available on request from the corresponding author. 
Conflicts of Interest: The authors declare no conflict of interest.

\section{References}

1. World Health Organization. Obesity and Overweight. Available online: https://www.who.int/en/newsroom/fact-sheets/ detail/obesity-and-overweight (accessed on 20 December 2020).

2. Maurizi, G.; Della Guardia, L.; Maurizi, A.; Poloni, A. Adipocytes properties and crosstalk with immune system in obesity-related inflammation. J. Cell. Physiol. 2018. [CrossRef]

3. Maurizi, G.; Petäistö, T.; Maurizi, A.; Della Guardia, L. Key-genes regulating the liposecretion process of mature adipocytes. J. Cell. Physiol. 2018. [CrossRef]

4. Giordano, A.; Frontini, A.; Cinti, S. Convertible visceral fat as a therapeutic target to curb obesity. Nat. Rev. Drug Discov. 2016. [CrossRef]

5. Ouellet, V.; Labbé, S.M.; Blondin, D.P.; Phoenix, S.; Guérin, B.; Haman, F.; Turcotte, E.E.; Richard, D.; Carpentier, A.C. Brown adipose tissue oxidative metabolism contributes to energy expenditure during acute cold exposure in humans. J. Clin. Investig. 2012, 122, 545-552. [CrossRef]

6. Rolfe, D.F.; Brown, G.C. Cellular energy utilization and molecular origin of standard metabolic rate in mammals. Physiol. Rev. 1997, 77, 731-758. [CrossRef]

7. Ruige, J.B.; Ballaux, D.P.; Funahashi, T.; Mertens, I.L.; Matsuzawa, Y.; Van Gaal, L.F. Resting metabolic rate is an important predictor of serum adiponectin concentrations: Potential implications for obesity-related disorders. Am. J. Clin. Nutr. 2005, 82, 21-25. [CrossRef]

8. Astrup, A.; Buemann, B.; Toubro, S.; Ranneries, C.; Raben, A. Low resting metabolic rate in subjects predisposed to obesity: A role for thyroid status. Am. J. Clin. Nutr. 1996, 63, 879-883. [CrossRef] [PubMed]

9. Ravussin, E.; Lillioja, S.; Knowler, W.C.; Christin, L.; Freymond, D.; Abbott, W.G.; Boyce, V.; Howard, B.V.; Bogardus, C. Reduced Rate of Energy Expenditure as a Risk Factor for Body-Weight Gain. New Engl. J. Med. 1988, 318, 467-472. [CrossRef] [PubMed]

10. Palmer, B.F.; Clegg, D.J. Non-shivering thermogenesis as a mechanism to facilitate sustainable weight loss. Obes. Rev. 2017, 18, 819-831. [CrossRef] [PubMed]

11. Browning, M.G.; Evans, R.K. The contribution of fat-free mass to resting energy expenditure: Implications for weight loss strategies in the treatment of adolescent obesity. Int. J. Adolesc. Med. Health 2015, 27, 241-246. [CrossRef]

12. Vallerand, A.L.; Jacobs, I. Rates of energy substrates utilization during human cold exposure. Graefe's Arch. Clin. Exp. Ophthalmol. 1989, 58, 873-878. [CrossRef] [PubMed]

13. Fonda, B.; De Nardi, M.; Sarabon, N. Effects of whole-body cryotherapy duration on thermal and cardio-vascular response. J. Therm. Biol. 2014, 42, 52-55. [CrossRef] [PubMed]

14. Lubkowska, A.; Dudzińska, W.; Bryczkowska, I.; Dołegowska, B. Body Composition, Lipid Profile, Adipokine Concentration, and Antioxidant Capacity Changes during Interventions to Treat Overweight with Exercise Programme and Whole-Body Cryostimulation. Oxidative Med. Cell. Longev. 2015, 2015, 1-13. [CrossRef] [PubMed]

15. Wiecek, M.; Szymura, J.; Sproull, J.; Szygula, Z. Whole-Body Cryotherapy Is an Effective Method of Reducing Abdominal Obesity in Menopausal Women with Metabolic Syndrome. J. Clin. Med. 2020, 9, 2797. [CrossRef] [PubMed]

16. Bouzigon, R.; Grappe, F.; Ravier, G.D.B. Whole- and partial-body cryostimulation/cryotherapy: Current technologies and practical applications. J. Therm Biol. 2016, 61, 61-67. [CrossRef]

17. Mannocci, A.; Di Thiene, D.; Del Cimmuto, A. International Physical Activity Questionnaire: Validation and assessment in an Italian sample. Ital. J. Public Heal. 2010, 7, 369-376.

18. Ekelund, U.; Ward, A.H.; Norat, T.; Luan, J.; May, A.M.; Weiderpass, E.; Sharp, S.J.; Overvad, K.; Østergaard, J.N.; Tjønneland, A.; et al. Physical activity and all-cause mortality across levels of overall and abdominal adiposity in European men and women: The European Prospective Investigation into Cancer and Nutrition Study (EPIC). Am. J. Clin. Nutr. 2015, 101, 613-621. [CrossRef]

19. Welch, A.A.; Luben, R.; Khaw, K.T.; Bingham, S.A. The CAFE computer program for nutritional analysis of the EPIC-Norfolk food frequency questionnaire and identification of extreme nutrient values. J. Hum. Nutr. Diet. 2005, 18, 99-116. [CrossRef]

20. Dupertuis, Y.M.; Oshima, T.; Delsoglio, M.; Achamrah, N.; Heidegger, C.; Pichard, C. In Vitro validation of the new indirect calorimeter for very low $\mathrm{O}_{2}$ consumption and $\mathrm{CO}_{2}$ production. Clin. Nutr. 2018, 37, s175. [CrossRef]

21. Groeneveld, R.A.; Meeden, G. Measuring Skewness and Kurtosis. J. R. Stat. Soc. Ser. D (Stat.) 1984, 33, 391. [CrossRef]

22. Cohen, J. Statistical Power Analysis for the Behavioral Sciences, 2nd ed.; Academic Press: New York, NY, USA, 1988.

23. Beyer, H.; Tukey, J.W. Exploratory Data Analysis. Addison-Wesley Publishing Company Reading, Mass. Menlo Park, Cal., London, Amsterdam, Don Mills, Ontario, Sydney 1977, XVI, 688. 1981. S. Biom. J. 1981, 23, 413-414. [CrossRef]

24. Loap, S.L.R. Mechanism Underlying Tissue Cryotherapy to Combat Obesity/Overweight: Triggering Thermogenesis. J. Obes. 2018, 2018, 5789647. [CrossRef] [PubMed]

25. Carneiro, I.P.; Elliott, S.A.; Siervo, M.; Padwal, R.; Bertoli, S.; Battezzati, A.; Prado, C.M. Is Obesity Associated with Altered Energy Expenditure? Adv. Nutr. 2016, 7, 476-487. [CrossRef] [PubMed]

26. Wehling, H.; Lusher, J. People with a body mass index $\geq 30$ under-report their dietary intake: A systematic review. J. Health Psychol. 2019, 24, 2042-2059. [CrossRef] [PubMed]

27. Nowack, J.; Giroud, S.; Arnold, W.; Ruf, T. Muscle Non-shivering Thermogenesis and Its Role in the Evolution of Endothermy. Front. Physiol. 2017, 8, 889. [CrossRef] 
28. Sahoo, S.K.; Shaikh, S.A.; Sopariwala, D.H.; Bal, N.C.; Periasamy, M. Sarcolipin Protein Interaction with Sarco(endo)plasmic Reticulum Ca2+ATPase (SERCA) Is Distinct from Phospholamban Protein, and Only Sarcolipin Can Promote Uncoupling of the SERCA Pump. J. Biol. Chem. 2013, 288, 6881-6889. [CrossRef] [PubMed]

29. Richard, M.A.; Pallubinsky, H.B.D. Functional characterization of human brown adipose tissue metabolism. Biochem. J. 2020, 477, 261-1286. [CrossRef]

30. Blondin, D.P.; Daoud, A.; Taylor, T.; Tingelstad, H.C.; Bézaire, V.; Richard, D.; Carpentier, A.C.; Taylor, A.W.; Harper, M.-E.; Aguer, C.; et al. Four-week cold acclimation in adult humans shifts uncoupling thermogenesis from skeletal muscles to brown adipose tissue. J. Physiol. 2017, 595, 2099-2113. [CrossRef]

31. Dulian, K.; Laskowski, R.; Grzywacz, T.; Kujach, S.; Flis, D.J.; Smaruj, M.; Ziemann, E. The whole body cryostimulation modifies irisin concentration and reduces inflammation in middle aged, obese men. Cryobiology 2015, 71, 398-404. [CrossRef]

32. Zhang, Y.; Li, R.; Meng, Y.; Li, S.; Donelan, W.; Zhao, Y.; Qi, L.; Zhang, M.; Wang, X.; Cui, T.; et al. Irisin Stimulates Browning of White Adipocytes through Mitogen-Activated Protein Kinase p38 MAP Kinase and ERK MAP Kinase Signaling. Diabetes 2014, 63, 514-525. [CrossRef] [PubMed]

33. Pfannenberg, C.; Werner, M.K.; Ripkens, S.; Stef, I.; Deckert, A.; Schmadl, M.; Reimold, M.; Häring, H.-U.; Claussen, C.D.; Stefan, N. Impact of Age on the Relationships of Brown Adipose Tissue with Sex and Adiposity in Humans. Diabetes 2010, 59, 1789-1793. [CrossRef]

34. Yoneshiro, T.; Aita, S.; Matsushita, M.; Kayahara, T.; Kameya, T.; Kawai, Y.; Iwanaga, T.; Saito, M. Recruited brown adipose tissue as an antiobesity agent in humans. J. Clin. Investig. 2013, 123, 3404-3408. [CrossRef]

35. Jung, R.T.; Shetty, P.S.; James, W.P.T.; Barrand, M.A.; Callingham, B.A. Reduced thermogenesis in obesity. Nat. Cell Biol. 1979, 279, 322-323. [CrossRef]

36. Periasamy, M.; Maurya, S.K.; Sahoo, S.K.; Singh, S.; Reis, F.C.G.; Bal, N.C. Role of SERCA Pump in Muscle Thermogenesis and Metabolism. Compr. Physiol. 2017, 7, 879-890. [CrossRef]

37. Thurlby, P.L.; Trayhurn, P. The role of thermoregulatory thermogenesis in the development of obesity in genetically-obese (ob/ob) mice pair-fed with lean siblings. B. Br. J. Nutr. 1979, 42, 377-385. [CrossRef]

38. Wu, H.; Ballantyne, C.M. Skeletal muscle inflammation and insulin resistance in obesity. J. Clin. Investig. 2017, 127, 43-54. [CrossRef] [PubMed]

39. Berggren, J.R.; Hulver, M.W.; Dohm, G.L.; Houmard, J.A. Weight Loss and Exercise: Implications for Muscle Lipid Metabolism and Insulin Action. Med. Sci. Sports Exerc. 2004, 36, 1191-1195. [CrossRef]

40. de Mello, A.H.; Costa, A.B.; Engel, J.D.G.; Rezin, G.T. Mitochondrial dysfunction in obesity. Life Sci. 2018, 192, 26-32. [CrossRef]

41. Wold, L.E.; Dutta, K.; Mason, M.M.; Ren, J.; Cala, S.E.; Schwanke, M.L.; Davidoff, A.J. Impaired SERCA function contributes to cardiomyocyte dysfunction in insulin resistant rats. J. Mol. Cell. Cardiol. 2005, 39, 297-307. [CrossRef] [PubMed]

42. Lee, Y.; Chakraborty, S.; Muthuchamy, M. Roles of sarcoplasmic reticulum $\mathrm{Ca}^{2+}$ ATPase pump in the impairments of lymphatic contractile activity in a metabolic syndrome rat model. Sci. Rep. 2020, 10, 1-20. [CrossRef] [PubMed]

43. Corpeleijn, E.; Mensink, M.; Kooi, M.E.; Roekaerts, P.M.; Saris, W.H.; Blaak, E.E. Impaired Skeletal Muscle Substrate Oxidation in Glucose-intolerant Men Improves After Weight Loss. Obesity 2008, 16, 1025-1032. [CrossRef]

44. Flachs, P.; Rossmeisl, M.; Kuda, O.; Kopecky, J. Stimulation of mitochondrial oxidative capacity in white fat independent of UCP1: A key to lean phenotype. Biochim. Biophys. Acta (BBA) Mol. Cell Biol. Lipids 2013, 1831, 986-1003. [CrossRef]

45. Xu, Z.; You, W.; Zhou, Y.; Chen, W.; Wang, Y.; Shan, T. Cold-induced lipid dynamics and transcriptional programs in white adipose tissue. BMC Biol. 2019, 17, 1-21. [CrossRef] [PubMed]

46. Fischer, A.W.; Csikasz, R.I.; von Essen, G.; Cannon, B.; Nedergaard, J. No insulating effect of obesity. Am. J. Physiol Endocrinol Metab. 2016, 311, E202-E213. [CrossRef] [PubMed]

47. Olichon-Berthe, C.; Van Obberghen, E.; Le Marchand-Brustel, Y. Effect of cold acclimation on the expression of glucose transporter Glut 4. Mol. Cell. Endocrinol. 1992, 89, 11-18. [CrossRef]

48. Shin, H.; Ma, Y.; Chanturiya, T.; Cao, Q.; Wang, Y.; Kadegowda, A.K.; Jackson, R.; Rumore, D.; Xue, B.; Shi, H.; et al. Lipolysis in Brown Adipocytes Is Not Essential for Cold-Induced Thermogenesis in Mice. Cell Metab. 2017, 26, 764-777.e5. [CrossRef]

49. Chitraju, C.; Fischer, A.W.; Farese, R.V.; Walther, T.C. Lipid Droplets in Brown Adipose Tissue Are Dispensable for Cold-Induced Thermogenesis. Cell Rep. 2020, 33, 108348. [CrossRef]

50. Geer, E.B.; Shen, W. Gender differences in insulin resistance, body composition, and energy balance. Gend. Med. 2009, 6, 60-75. [CrossRef] 